\title{
Identification and characterization of the zebrafish ClC-2 chloride channel orthologs
}

\author{
Carla Pérez-Rius • Héctor Gaitán-Peñas • Raúl Estévez • \\ Alejandro Barrallo-Gimeno
}

Received: 30 July 2014 /Revised: 9 September 2014 / Accepted: 9 September 2014

(C) Springer-Verlag Berlin Heidelberg 2014

\begin{abstract}
ClC}-2$ is a $\mathrm{Cl}^{-}$channel that belongs to the CLC family of chloride channel/transport proteins. ClC-2 molecular role is not clear, and Clcn 2 knockout mice develop blindness, sterility, and leukodystrophy by unknown reasons. ClC2 is associated in the brain with the adhesion molecule GlialCAM, which is defective in a type of leukodystrophy, involving $\mathrm{ClC}-2$ in the homeostasis of myelin. To get more insight into the functions of $\mathrm{ClC}-2$, we have identified in this work the three ClC-2 orthologs in zebrafish. clcn $2 a$ and $c l c n 2 b$ resulted from the teleost-specific whole genome duplication, while $\operatorname{clcn} 2 c$ arose from a gene duplication from $c l c n 2 b$. The expression patterns in adult tissues and embryos of zebrafish clcn2 paralogs support their subfunctionalization after the duplications, with $\operatorname{clcn} 2 a$ being enriched in excitable tissues and $c l c n 2 c$ in ionocytes. All three zebrafish clc-2 proteins interact with human GLIALCAM, that is able to target them to cell junctions, as it does with mammalian ClC-2. We could detect clc-2a and clc-2b inward rectified chloride currents with different voltage-dependence and kinetics in Xenopus oocytes, while clc-2c remained inactive. Interestingly, GlialCAM proteins did not modify clc- $2 b$ inward rectification. Then, our work extends the repertoire of
\end{abstract}

CPR and HGP contributed equally to this work.

Electronic supplementary material The online version of this article (doi:10.1007/s00424-014-1614-z) contains supplementary material, which is available to authorized users.

C. Pérez-Rius $\cdot$ H. Gaitán-Peñas $\cdot$ R. Estévez $(\bowtie) \cdot$

A. Barrallo-Gimeno $(\triangle)$

Departament de Ciències Fisiològiques II, Unitat de Fisiologia,

Universitat de Barcelona, Carrer Feixa Llarga s/n, L'Hospitalet de

Llobregat 08907, Barcelona, Spain

e-mail: restevez@ub.edu

e-mail: abarrallo@ub.edu

R. Estévez $\cdot$ A. Barrallo-Gimeno

U750, Centro de Investigación Biológica en Red de Enfermedades

Raras (CIBERER), Instituto de Salud Carlos III, Barcelona, Spain
ClC-2 proteins and provides new tools for structure-function and physiology studies.

Keywords $\mathrm{ClC}-2 \mathrm{Cl}^{-}$channel $\cdot$ In situ hybridization . Xenopus oocyte $\cdot$ Genome duplication $\cdot$ Zebrafish $\cdot$ GlialCAM

\section{Introduction}

Chloride is the main anion with biological functions. It is involved in a plethora of roles, such as cell volume regulation, transepithelial fluid movement, muscle contraction, charge compensation, and acidification of intracellular organelles. Cellular chloride levels are actively regulated by different co-transporters, exchangers, and channels [7]. Among them, $\mathrm{ClC}$ proteins, which are found in all phyla, in vertebrates constitute a family of proteins divided in two subgroups: one group of intracellular $\mathrm{Cl}^{-} / \mathrm{H}^{+}$exchangers with five members, and another group of $\mathrm{Cl}^{-}$channels located at the plasma membrane [22]. This latter group is formed by four members in mammals: $\mathrm{ClC}-1$, expressed in the skeletal muscle and involved in myotonia congenita [29, 48, 49]; ClC-Ka and $\mathrm{ClC}-\mathrm{Kb}$, expressed in renal tubules and the inner ear, responsible for some variants of Bartter's syndrome (reviewed in [13]); and ClC-2, broadly expressed in many tissues [51], that has been involved in a leukodystrophy which develops with intramyelinic oedema [6].

$\mathrm{ClC}$ proteins function as homodimers $[36,38]$, and every subunit contains one ion pore [8]. These two ion pores operate independently of each other, but there is a common gating mechanism which affects both pores simultaneously, as first deduced by Miller [39]. Heterologous expression of heterodimeric chloride channels has shown that there are intersubunit interactions that affect individual and common gating [35, 50, 54]. ClC-2 is activated by membrane hyperpolarization, extracellular acidic $\mathrm{pH}$, cell swelling, and an increase in 
intracellular chloride concentration [16, 25]. Despite its broad expression and the relevant attributed functions, the phenotype of the $C l c n 2$ knockout mice is restricted to three aspects: degeneration of photoreceptors in the retina, degeneration of the testes [2], and, later in life, the development of vacuolization of the central nervous system myelin [1]. All of them point to an important unknown role of ClC-2 in regulating ionic concentrations of small extracellular spaces. Other proposed roles of $\mathrm{ClC}-2$, like fluid secretion in salivary glands $[40,46]$ or in the intestines $[4,56]$, have been shown to be nonessential in the $C l c n 2$ knockout mice.

Some ClC channels require of specific beta subunits for their proper localization and activity (i.e., $\mathrm{ClC}-\mathrm{Ka} / \mathrm{b}$ and Barttin [10], ClC-7, and Ostm1 [30]). ClC-2 interacts with the cell adhesion molecule GlialCAM, which is responsible for its subcellular localization in glial cells, increases ClC-2mediated currents, and changes its functional properties [24]. Differently from other $\mathrm{ClC}$ subunits, GlialCAM is able to interact not only with $\mathrm{ClC}-2$, but with all $\mathrm{ClC}$ channels in vitro and activate them by stabilizing the open configuration of the common gate [23]. GLIALCAM is mutated in a rare form of leukodystrophy called megalencephalic leukoencephalopathy with subcortical cysts (MLC) [34]. The absence of GlialCAM in knockout mice leads to the intracellular retention of $\mathrm{ClC}-2$ in glial cells and functional defects in the activity of $\mathrm{ClC}-2$ in oligodendrocytes, proving that the activation of ClC-2 by GlialCAM in vitro is also seen in vivo [18], and suggesting that part of the phenotype of MLC disease is caused by a dysfunction of ClC-2 activity.

Zebrafish is proven as a valuable animal model due to its genetic tractability, not only for embryonic development, as it was originally conceived [17], but also for studying adaptive physiology [21] or reproducing disease phenotypes [32, 43]. We have previously generated a zebrafish MLC model, in which some of the molecular features of the disease are conserved [47]. In this work, we have identified the zebrafish clcn 2 orthologous genes, and characterized their expression patterns, subcellular localization, interaction with GLIALCAM homologues, and electrophysiological properties in Xenopus oocytes.

\section{Methods}

Animals

Zebrafish were kept at the animal facility in Bellvitge Campus, University of Barcelona, under standard conditions at $28{ }^{\circ} \mathrm{C}$, and $14 \mathrm{~h} \mathrm{light} / 10 \mathrm{~h}$ dark cycle. Wild-type $\mathrm{AB}$ and tup/lof lines were used. All experimental procedures conformed to the European Community Guidelines on Animal Care and Experimentation and were approved by animal care and use committees.
RNA expression

Adult zebrafish or embryos were euthanized using an overdose of tricaine (MS222, Sigma). Adult tissues were quickly dissected and flash-frozen in liquid nitrogen. Total RNA was isolated with TRIzol (Life Technologies) and retrotranscribed using random hexamers with the SuperScript III system (Life Technologies).

The following oligonucleotides pairs were used for qPCR: CCTACAGCCCCACGTTGACT and GGTTTGGAGAGC TGTTGAGTGA ( $c l c n 2 a)$, TCTCTTCAAGACGCGCTTCA and CGATCAGCCTGTTCAGATACACA $(c l c n 2 b)$, and ACGTCTTCGTCGTCCTCTTTG and CAGCACCGATGA CGAAAATG ( $\operatorname{lcn} 2 c)$; and as internal controls: CTGGAG GCCAGCTCAAACAT and ATCAAGAAGAGTAGTACC GCTACCATTAC (efla), TCTGGAGGACTGTAAGAGGT ATGC and AGACGCACAATCTTGAGAGCAG (rpll3a).

qPCR was performed with SYBR Select reagent (Life Technologies) in a StepOne apparatus (Life Technologies). Three experiments were analyzed, with three replicate samples in every experiment. The expression levels were calculated using the comparative $\mathrm{C}_{\mathrm{t}}$ method normalized to the internal control genes. The final results were expressed as the relative messenger RNA (mRNA) levels as indicated in the corresponding figures, taking into account the efficiency of each primer pair with the Pfaffl method [42].

Discrepancies between predicted sequences from the zebrafish genome were solved by reverse transcription polymerase chain reaction (RT-PCR) using the appropriate pairs of primers and RNA from adult brain, using the SuperScript III One-Step RT-PCR with Platinum Taq system (Invitrogen).

\section{Whole mount in situ hybridization}

Fragments of every gene of around 1-kb length were amplified from 7 dpf embryo RNA, cloned into the pGEM-T Easy vector (Promega) and sequenced. The resulting plasmids were linearized and transcribed with the appropriate RNA polymerase to generate antisense riboprobes, labeled with digoxigenin (Roche).

After fixing zebrafish embryos at the desired stages in $4 \%$ paraformaldehyde in phosphate-buffered saline (PBS) overnight at $4{ }^{\circ} \mathrm{C}$, they were dehydrated through a methanol-PBS series and kept at $-20{ }^{\circ} \mathrm{C}$ until use. Before hybridization, embryos were rehydrated through a PBS-methanol series and then digested with proteinase $\mathrm{K}$ for permeabilization, post-fixed with PFA $4 \%$ for $20 \mathrm{~min}$ at room temperature (RT), and washed with PBS. Then, they were incubated in hybridization solution (50 \% formamide, saline-sodium citrate (SSC) $5 \times, 2 \%$ Roche blocking powder, $0.1 \%$ Tween, $50 \mathrm{mg} /$ $\mathrm{mL}$ heparin, $1 \mathrm{mg} / \mathrm{mL}$ yeast RNA, $1 \mathrm{mM}$ EDTA, $0.1 \%$ CHAPS, and DEPC-treated water) at $60{ }^{\circ} \mathrm{C}$ overnight. Embryos were hybridized the next day with digoxigenin-labeled 
riboprobes and incubated at $60^{\circ} \mathrm{C}$ with gentle agitation during 2 days. Unbound riboprobes were washed away using SSC $2 \times$ (from SSC $20 \times$ stock solution: $3 \mathrm{M} \mathrm{NaCl}, 0.3 \mathrm{M}$ sodium citrate, $\mathrm{pH} 7.0$ ) CHAPS $0.1 \%$ for 5 min twice, followed by three more times with SSC $2 \times$ CHAPS $0.1 \%$ for $20 \mathrm{~min}$, and finally washed three times with SSC $0.2 \times$ CHAPS $0.1 \%$ for $20 \mathrm{~min}$. All these washing steps were performed at $60{ }^{\circ} \mathrm{C}$. Afterwards, we used KTBT (50 mM Tris- $\mathrm{HCl}, \mathrm{pH} 7.5$, $150 \mathrm{mM} \mathrm{NaCl}, 10 \mathrm{mM} \mathrm{KCl}, 0.1 \%$ Tween-20) thrice for $5 \mathrm{~min}$ at room temperature. Then, we proceeded to add blocking solution (20\% iFBS, $0.7 \%$ Roche blocking powder in KTBT) to avoid unspecific binding of the anti-DIG antibody, agitating for several hours, and then added APconjugated anti-DIG antibody (dilution 1:1000), incubating at $6{ }^{\circ} \mathrm{C}$ overnight. The next day, we washed embryos with KTBT along the day with numerous solution changes, and kept them overnight with PBS-T (PBS, $0.1 \%$ Tween-20). Then, after washing thrice the embryos with NTMT (100 mM Tris-HCl, pH 9.5, $50 \mathrm{mM} \mathrm{MgCl2,} 100 \mathrm{mM} \mathrm{NaCl}$, $0.1 \%$ Tween-20; $1 \mathrm{mM}$ levamisole) for $10 \mathrm{~min}$, staining solution ( $3 \mu \mathrm{L} / \mathrm{mL}$ NBT, $2.3 \mu \mathrm{L} / \mathrm{mL}$ BCIP in NTMT) was added and kept in the dark at room temperature with gentle agitation until a blue precipitate could be seen. Once the hybridizations were developed, we proceeded to wash embryos twice with PBS-T for $5 \mathrm{~min}$ and twice for $30 \mathrm{~min}$, and then stored at $4{ }^{\circ} \mathrm{C}$.

Embryos were photographed on a Nikon SMZ800 stereoscope equipped with a Nikon DS-2Mv digital camera. Images were adjusted for brightness and contrast using NIH ImageJ.

For sectioning, embryos were embedded in a gelatinalbumin-sucrose mixture in PBS for $16 \mathrm{~h}$ at $4{ }^{\circ} \mathrm{C}$, then blocks with the embryos at the appropriate orientation were polymerized with glutaraldehyde and post-fixed in PFA $4 \%$ in PBS overnight at $4{ }^{\circ} \mathrm{C}$. Blocks were sectioned at $30-\mu \mathrm{m}$ thickness in a Leica vibratome, sections floated in PBS and mounted on slides with Mowiol (Calbiochem).

Cell line transfection, immunofluorescence, and microscopy

Full-length complementary DNAs (cDNAs) of the three zebrafish clc-2 channels (Figs. S1 and S2 ESM for clc-2a and $\mathrm{b}$ ), plus the human $\mathrm{ClC}-2$ channel, were cloned into pcDNA3 plasmid vector using the Gateway system (Invitrogen) to add a FLAG or HA tags at their carboxy terminus.

HeLa cells were grown on DMEM containing $10 \%(v / v)$ fetal bovine serum (Sigma) and $1 \%$ penicillin/streptomycin at $37^{\circ} \mathrm{C}$ in a humidity controlled incubator with $10 \% \mathrm{CO}_{2}$. Cells were transfected with the chloride channels alone or with the human GLIALCAM using the TransFectin lipid reagent (BioRad). Twenty four hours after transfection, cells were splitted and transferred into petri dishes with cover glasses, in which experiments were performed after further $24 \mathrm{~h}$. Cells were fixed with $3 \%$ paraformaldehyde in PBS for $15 \mathrm{~min}$, blocked and permeabilized with $0.1 \%$ Triton X-100 in PBS with $10 \%$ FBS for $2 \mathrm{~h}$ at RT. Primary antibodies (anti-Flag 1:500 (Sigma), anti-HA 1:500 (Roche) or anti-GLIALCAM $1: 100$ [34]) were diluted in the same solution and incubated overnight at $4{ }^{\circ} \mathrm{C}$. Cells were washed with the blocking solution and incubated for $2 \mathrm{~h}$ at RT with fluorescently labeled secondary antibodies (1:500, Invitrogen), subsequently washed with PBS. Coverslips were mounted in Vectashield medium (Vector Laboratories) with $1.5 \mu \mathrm{g} / \mathrm{mL}$ DAPI (Sigma) and visualized using an Olympus DSU spinning disk confocal microscope.

\section{Two-electrode voltage clamp in Xenopus oocytes}

Xenopus oocytes were injected and maintained as described [12]. For all zebrafish clc-2 channels, 8-10 ng of cRNA were injected in each oocyte. When performing co-expression experiments, $5 \mathrm{ng}$ of cRNA of glialcama or glialcamb or $2 \mathrm{ng}$ of human GLIALCAM were co-injected with the indicated clc-2 channel. Measurements were done in ND96 medium (96 mM sodium chloride, $2 \mathrm{mM}$ potassium chloride, $1.8 \mathrm{mM}$ calcium chloride, $1 \mathrm{mM}$ magnesium chloride, and $5 \mathrm{mM}$ HEPES buffer at $\mathrm{pH}$ 7.4). For selectivity experiments, $80 \mathrm{mM} \mathrm{Cl}^{-}$ was substituted by equivalent amounts of $\mathrm{Br}^{-}, \mathrm{I}^{-}$, or $\mathrm{NO}_{3}{ }^{-}$. For $\mathrm{pH}$ experiments, at $\mathrm{pH} 5.4$ or 6.4, HEPES was replaced by $5 \mathrm{mM}$ MES buffer, and at pH 8.4 by $5 \mathrm{mM}$ Tris buffer. The voltage protocol was of an initial $100 \mathrm{~ms}$ voltage pulse at $-30 \mathrm{mV}$, followed by $4 \mathrm{~s}$ voltage steps from +80 to $-140 \mathrm{mV}$ in $20 \mathrm{mV}$ increments, and a tail pulse of $1 \mathrm{~s}$ at $+40 \mathrm{mV}$, followed by another $100 \mathrm{~ms}$ pulse at $-30 \mathrm{mV}$. The currents were measured using a TEC-05X voltage amplifier and the CellWorks program (npi). Off-line analysis was performed using pClamp9 (Axon Instruments) and SigmaPlot.

In order to compare the currents of $\mathrm{ClC}-2$, we used a similar method to the one described in Jeworutzki et al. [23]. Oocytes were first pulsed to $+40 \mathrm{mV}$ to estimate the instantaneous activated current under resting conditions and then activated with a long pulse to $-140 \mathrm{mV}$. The following tail pulse to + $40 \mathrm{mV}$ induced current deactivation, which can be described with a double exponential kinetics. The ratio between the $\mathrm{I}_{\min }$ (resting state currents) and the $\mathrm{I}_{\max }$ of the tail pulse indicates the preference of the channel for the open configuration.

\section{Results}

Identification of the zebrafish repertoire of clc- 2 channels

In order to identify the zebrafish clcn2 orthologs, we inspected the ENSEMBL and NCBI databases. We were surprised to find three orthologous genes instead of the usual two copies, 
as is the case for many genes as a result of the teleost-specific genome duplication [19]. We named these genes clcn2a (ENSDARG00000062427, located in chromosome 2, NCBI XM 001920901), clcn2b (ENSDARG00000074681, located in a non-assigned scaffold, NCBI XM_002667675), and clcn2c (ENSDARG00000060439, located in chromosome 15, NCBI XM_686813). We also found three clcn2 orthologues in two other fish species: the Mexican tetra (Astyanax mexicanus) and the Nile tilapia (Oreochromis niloticus) (Fig. 1). Therefore, this extra clcn2 gene is not a zebrafish-specific event.

We noted several differences between the predicted protein sequences of clc- $2 a$ and clc- $2 b$ in the ENSEMBL and NCBI databases (Figs. S1 and S2). Neither NCBI nor ENSEMBL had identified the first exon of clcn2a. We used several exon prediction programs (geneid, GeneScan), but they failed to recognize a likely exon in $100 \mathrm{~kb}$ of genomic sequence upstream of the predicted start codon. Using the conserved peptide RALQYEQTL, present in the first exon of mammalian $C L C N 2$ and also zebrafish $c l c n 2 b$ (see Fig. 2), we performed a BLAST search against the mentioned genomic sequence. We identified a predicted initial exon approximately $58 \mathrm{~kb}$ upstream of the originally predicted start site, and whose transcription we confirmed by RT-PCR and sequencing. Furthermore, NCBI prediction for clc-2a had a 600 aminoacids insertion at the end of exon 19; we disregarded this sequence, as it had no homology to any $\mathrm{ClC}$ protein. Also, NCBI prediction introduced six aminoacids at the beginning of exon 23 (VKTLPR), which we did not find by RT-PCR. On the other hand, the ENSEMBL prediction incorporated a small exon coding for eight aminoacids (EEPFEGNK) between exons 6 and 7 and did not incorporate exon 20; we confirmed by RT-PCR that both of them are alternative exons (in green in Fig. S1).

In the case of clcn2b, NCBI prediction did not identify exon 1 ; there was a four aminoacids insertion at the beginning of exon 8, exons 9 to 12 were not incorporated, and exons 16 and 17 were not correctly spliced (Fig. S2). We could not find exon 20 in our RT-PCR experiments, but given its sequence conservation, we cannot rule out that it is an alternative exon (in green in Fig. S2), as it is in clcn2a. All the remaining differences were resolved by RT-PCR (primers available upon request) and sequencing to get the full-length cDNAs of every zebrafish clc-2 channel, which were obtained by gene synthesis.

With the definitive protein sequences, we performed a phylogenetic analysis with the other $\mathrm{ClC}$ channels belonging to the plasma membrane subfamily, $\mathrm{ClC}-1$ and $\mathrm{ClC}-\mathrm{Ka} / \mathrm{Kb}$, to assure that the three genes we had found were true $\mathrm{ClC}-2$ orthologues. Of note, zebrafish genome shows two orthologues to $\mathrm{ClC}-1$, but just one to $\mathrm{ClC}-\mathrm{Ka} / \mathrm{Kb}$, as it was previously described [55]. We aligned the predicted protein sequences using the CLUSTALW program, performed a

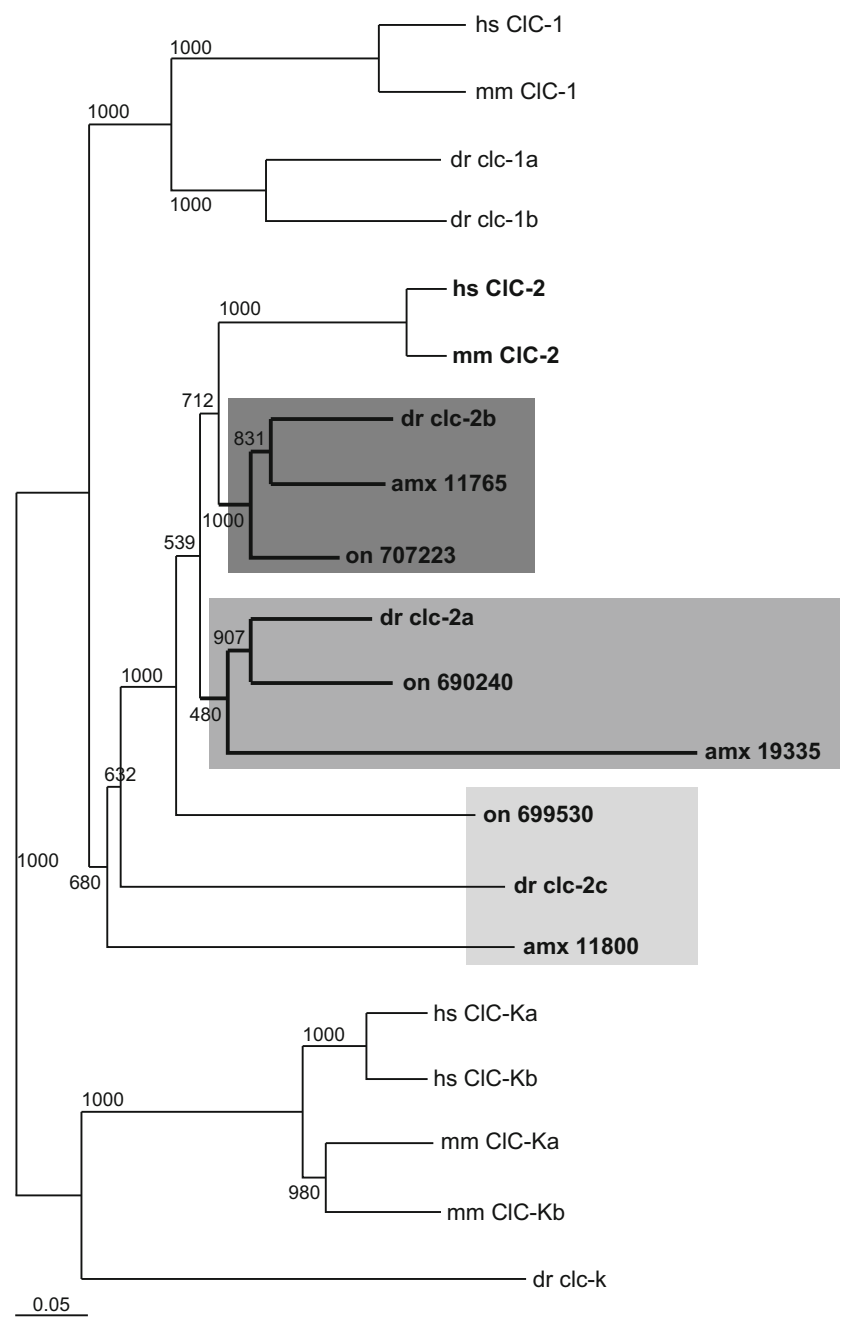

Fig. 1 Phylogenetic analysis of $\mathrm{ClC}$ channels of the plasma membrane subfamily shows the triplication of the clc-2 channel in teleosts. $h s$ human, $m m$ mouse, $d r$ zebrafish (Danio rerio), amx Mexican tetra (Astyanax mexicanus), on Nile tilapia (Oreochromis niloticus). Sequences used for the other two teleosts were ENSAMXG00000011765, ENSAMXG00000011800, and ENSAMXG00000019335 for the Mexican tetra; LOC100690240, LOC100699530, and LOC100707223 for the Nile tilapia. Numbers in the tree represent bootstrap values

bootstrap analysis with 1000 replicates, and plotted the resulting phylogenetic tree using NJ plot program (Fig. 1). The three teleost clc-2 paralogs clustered together and with mammalian $\mathrm{ClC}-2$, therefore confirming their identity. clc-2a and $\mathrm{b}$ are more similar to mammalian $\mathrm{ClC}-2$, and the three teleost clc-2c are more distantly related, but still unequivocally ClC-2 orthologs.

No obvious synteny was observed with the mouse $\mathrm{Clcn} 2$ gene. Exon-intron boundaries were conserved between mammalian and zebrafish clc-2 orthologues (Fig. 2). Sequence conservation was high in the 17 predicted intramembrane $\alpha$ helices and the intracellular CBS domains, thought to be important for regulation of the channel [11]. The regions involved in the chloride selectivity [8] were perfectly conserved, with the exception of an Ala to Ser change in the 
hs $\mathrm{ClC}-2$ $\mathrm{mm} \mathrm{ClC}-2$ $\mathrm{dr}$ clc $-2 \mathrm{a}$ dr clc-2b dr $\mathrm{clc}-2 \mathrm{C}$ SILLQYLAWVTYPVLITFSAGFTQILAPQA hs $\mathrm{ClC}-2$ $\mathrm{mm} \mathrm{ClC}-2$ $\mathrm{dr} \mathrm{clc}-2 \mathrm{~b}$ dr $\mathrm{clc}-2 \mathrm{c}$ IALLLOAOKWMYGGLDS-NVVLOYLAWVTYPVVLISFSAGFTHIVAPOA VDLFTDAHRWIYYSVADYHVVVQYLVWVSYSMILMCFAAGFANIVSPQAV $: *: *: \quad$ : : $::: * * * . * *: *:: *: *: * * *:: *:: * * *$ RGIYTKSADRLGKGHCHRK

-MAAAAAEGMEPRALOYEOTI MYGRYTODLGAFAKEEAARIRLGGPEPWKGPPSSR-AAPELLFYGRSRCARCRVCSVRCHKFLVSRVGEDWIFLVLLGI MAAATAAAAAAAAAGEGMEPRALQYEQTLMYGRYTQELGAFAKEEAARIRLGGPEPWKGSPSAR-ATPELLEYGQSRCARCRICSVRCHKFLVSRVGEDWIFLVLLGLLMALVSWAMDYA 119 ---------MARDRAPQRVLQYQQTLMYGRYTQELGAYAKEEAARLREDGG--LRRTTSVRGQAPELLEYEKDPCAKCQVCTSRCKKFLISRVGEDWIFLILLGLLMALVSWAMDYT 106 MAVDGOEORALOYEOTLMYGRYTOELGVYAREEAARLREDGR--ORRSISERSPSLKLLEYEKGRCVKCRICAVHCORFLMSRVGEDWIFLILLGLVMALVSFVMDFC 106

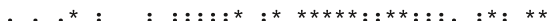

\section{G} $\mathrm{H}$

E hs $\mathrm{ClC}-2$ $\mathrm{mm} \mathrm{ClC}-2$ $\mathrm{dr} \mathrm{clc}-2$ dr clc-2b dr $\mathrm{clc}-2 \mathrm{c}$

hs $\mathrm{ClC}-2$ $\mathrm{mm} \mathrm{ClC-2}$

dr clc-2a dr clc-2b dr $\mathrm{clc}-2 \mathrm{c}$

hs $\mathrm{ClC}-2$ $\mathrm{mm} \mathrm{ClC}-2$ $\mathrm{dr} c l c-2 \mathrm{a}$ dr $c l c-2 b$ dr $\mathrm{clc}-2 \mathrm{c}$

ClC-2 $\mathrm{mm} \mathrm{ClC} 2$ dr clc $2 a$ $\mathrm{dr} \mathrm{clc} 2 \mathrm{~b}$ dr clc $2 \mathrm{c}$

hs $\mathrm{ClC}-2$ $\mathrm{dr}$ clc-2 dr clc-2 dr clc-2c

hs $\mathrm{ClC}-2$ $\mathrm{mm} \mathrm{ClC}-2$ dr clc-2a dr clc-2b dr $\mathrm{Clc}-2 \mathrm{c}$

ENESRNTEMLAAACAVGVGCCFAAPIGGVLFSIEVTSTFFAVRNYWRGFFAATFSAFIFRVLAVWNRDEETITALFKTRFRLDFPFDIOELPAFAVIGIASGFGGALFVYLNRKIVOVMR 350 EHESRNTEMLAAACAVGVGCCFAAPIGGVLFSIEVTSTFFAVRNYWRGFFAATFSAFIFRVLAVWNRDEETITALFKTRFRLDFPFDLQELPAFAVIGIASGFGGALFVYLNRKIVQVMR 358 MNELRNTEMLSAACAVGVGCCFAAPIGGVLFSIEVTSTFFAVRNYWRGFFAATFSAFIFRVLAVWNKDEETITALFKTRFRLDFPFDLQELPAFAVLGIASGFGGALYVYLNRIIVESMR 345 ENESRNIEMLAAACAVGVGCCFAAPIGGVLFSIEVTSTFFAVRNYWRGFFAATFSAFIFRVLAVWNRDEETITALFKTRFRLDFPFDLQELPAFAVIGIASGFGGALFVYLNRLIVQFMR 345 KNEARNKELLTVGCAVGIGCCFASPIGGALFSIEVTAMYYLPRNYWRAFLSATFGAIIFRLLPVWHREEETLMALYATKYRLDFPFDLOELPVFVAMGIVCGLGGAFFVFLYGKITLFVK 319

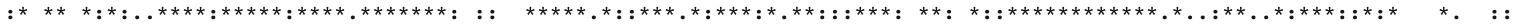

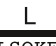

KOKTINRFLMRKRLLFPALVTLLISTLTFPPGFGQFMAGQLSQKETLVTLFD KQKTINRFLMRKRLLFPALVTLLISTLTFPPGFGQFMAGQLSQKETLVTLFD KOKTINKFLLKKRLVYPAVVTLLISTLTFPPGFGOFMAGOLTOHESLVALFD KOKTINKFLMKKRLLYPALVTLLISTLSFPPGFGOFMAGOLTOKETLVSFFD EKKASNSLLMRNCFYYSALTSVLISTLTFPPGFGQFMAGKLTQRYSLISFFDDRTW $:: *: * *::::::^{*}:::: * * * * *: * * * * * * * * *: *: *:: *::: * *$

$\mathrm{N}$

\section{O}

\section{$P$} GRLVGESMAWFPDI GRLVGESMAAFFPDGIHADSTVYPIVPGGYAVVGAAALSGAVTHTVSTAVIVFELTGQISHILPVMIAVILANAVAQSLQPSLYDSIIRIQKLPYLPELGWG-QEKYNIRVEDIMVRDVR 584 GRLVGESMAAWFPEGINTDGTIYPIVPGGYAVVGAAALSGAVTHTVSTAVIVFELTGQISHILPIMIAVILANAVAQSLQPSIYDSIIRIKKLPYLPELGWGHHEKYNIRVEDIMVRDVR 584 GRLIGEGMATLFPEGFNTDGHIYPIVPGAYAVVGAAALTAGVTHTMSTAVIMMELTGHLSYSLPILISVILSNMVSQSLQPSIYDTVIRIKRLPYLPLLRWGQRENSKIHVEDFMNRDVR 558

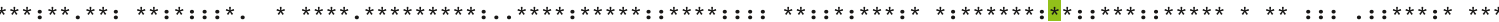

\section{CBS1}

HVALSCTFRDLRLALHRTKGRMLALVESPESMILLGSIERSQVVALLGAQLSPARRRQHMQERRATQTS------PLSDQEGPPTPEASVCFQVNTEDSAFPAARGETHKPLKPALKRGP 703 HVALSCTFRDLRLALHRTKGRMLALVESPESMILLGSIERSQVVALLGAQLSPARRRQHMQKLRKAQLS------PPSDQESPPSSETSIRFQVNTEDSGFSGAHGQTHKPLKPALKRGP 711 YITLSSSYRDLOEALVTGOLKTLALVESKESMILLGSIERSOLOSLLSOOLGRPRRLEYLRERAODNGTHV----PTFTPDSPPKAGRGVRFLISTEESSYSPTLTNSOIPLKSALKTVS 700 YITLNSTYRDLODILTIGNLKTVALVESADSMILLGSIERAOLQALLVOOVSRVRRQEVMRERAETERKRMSVASSPSSDDSSOKVNOEVRFOISTEESTFVPVRPISPKPLKPALKRTS 704 FITLNSTYRDVFKILCSGNLKTVPMVKSTESMLLLGSIERAQLLALL------IERTQYLRG------_----------GAYSIPARSKVHFQTATEDSSSASAQVSPSTPLKSALKRPT 655

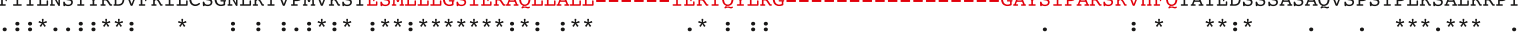
CBS2

SVTRNLGESPTGSAESAGIALRSLFCGSPPPEAASE--KLESCEK-RKLKRVRISLASDADLEGEMSPEEILEWEEOOLDEPVNFSDCKIDPAPFOLVERTSLHKTHTIFSLLGVDHAYV 820 SNSTSLOEGTTGNMESAGIALRSLFCSPPLFATSFLEKSESCDK-RKLKRVRISLASDSDPEAAMSPEFIIEWFEOOLEPVNFSDCKIDPAPFOLVERTSLHKTHTIFSLIGVDHAYV 830 AISNTDSLN-----SS-----PNLSCGEPVKELVESNAGPMAPKRSRRPKRVKIPMADTADVEDDMSTAEIAEWEEOOLDEAVNFNNCKIDPAPFOLVERTSLHKTHTIFSLLGLDHAYV 810 VAEKNIEIPTSPHDSSMG--LKNLLCARPQTDVMEE----SNNVELRQSKRVRISLLDDPDAEDDMTLGEIEEWEEQQLDEQVNFNSCKIDPAPFQLVERTSLHKTHTIFSLLGLDHAYV 801 ADEEQLN---NNVYDS-GLSFKTFFCSRPDTDAMK--------------------NDPDAHDDMILQEIEKWEEQQLDEQVNFNSCQIDPAPFQLVDRTTLHKTHSMFSVLNLDYAFV 749

* . . : * * : . . . : * $* *: * * * * * * * * * * * \ldots *: * * * * * * * *: * *: * * * * *:: * *: * .: *: *: *$

CBS2

SSIGRLIGIVTLKELRKAIEGSVTAQGVKVRPPLASFRDSATS--SSDTETTEVHALWGPHSRHGLPREGSPSDSDDKCQ TSTGRLVGVVSLKELRKAIEGSVTVTGVKVRPPLASFRDSGNS--SSVSEVTELHKLWSRHKSLSLPREINLPDLDDQTEQPSEGSLVNETECTELSSONSPLHTDDOSELPYADTSPOD 928

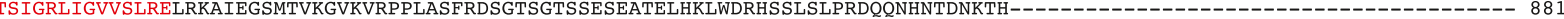

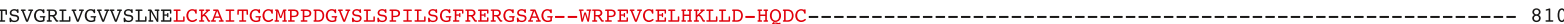

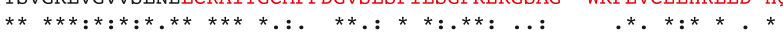

hs $\mathrm{ClC}-2$ $\mathrm{mm} \mathrm{ClC}-2$ $\mathrm{dr}$ clc $-2 \mathrm{a}$ $\mathrm{dr} c l c-2 \mathrm{~b}$ dr $\mathrm{clc}-2 \mathrm{c}$

EPLSQLPCDCPEVEESESVGEHCPESTVVVGDGNPSPSDGOPE 971

Fig. 2 Alignment of the predicted protein sequences of human, mouse, and zebrafish $\mathrm{ClC}-2$ channels performed with CLUSTALW. $\alpha$-helices are labeled with a black line and named according to Dutzler et al. [8]. CBS intracellular domains are marked with a blue line. Residues involved in chloride selectivity are highlighted with green background. Consensus glycosylation sequence is highlighted in blue. Exons are typed in alternate black and red colors. Asterisk identical residues among the five proteins, colon conserved residues, full stop similar residues beginning of helix $\mathrm{N}$ in clc-2c. Also, the glycosylation sequence $(\mathrm{N}-\mathrm{X}-\mathrm{S} / \mathrm{T})$ on the extracellular loop between helices $\mathrm{L}$ and $\mathrm{M}$ is conserved.

Interestingly, although zebrafish $\operatorname{clcn} 2 b$ is mapped to a non-assigned genomic scaffold, in the Mexican tetra genome, it is located adjacent to $c l c n 2 c$ and the chordin gene (scaffold KB882110.1). Zebrafish $c l c n 2 c$ is also in close proximity to chordin in chromosome 15 . Therefore, it seems likely that zebrafish $c l c n 2 b$ would also be next to $\operatorname{clcn} 2 c$. This situation is suggestive of a single-gene duplication event, similar to what happened to $\mathrm{ClC}-\mathrm{K}$ in mammals [26]. Then, the repertoire of clc-2 channels in teleosts would have arisen from the teleostspecific whole genome duplication to yield clc- $2 a$ and $b$, and an individual gene duplication from clc- $2 b$ to originate clc- $2 c$. 
Adult tissue mRNA expression

It has been shown that the evolutionary preservation of duplicated genes often implies their subfunctionalization [15]. One possibility is the restriction of the expression pattern of each gene [31], which in the case of the broadly expressed ClC-2 would be especially suitable. We analyzed the mRNA expression of the three $c l c n 2$ genes in adult tissues. We could observe that $\operatorname{clcn} 2 a$ is predominantly expressed in brain and eye (Fig. 3a), while $c l c n 2 b$ showed a broader distribution (Fig. 3b), and clcn $2 c$ was especially abundant in the gills (Fig. 3c). When we compared the expression levels of the three genes in every tissue (Fig. 3d), we could notice that clcn $2 a$ was the most expressed zebrafish clc- 2 channel in brain, eye, and heart; clcn $2 b$ in the intestine; and $\operatorname{clcn} 2 c$ in gills, kidney, testes, liver, and muscle. This scenario is compatible with a subfunctionalization process, where $\operatorname{clcn} 2 a$ is enriched in tissues with high electrical conduction, $c l c n 2 b$ is widely expressed as $\mathrm{ClC}-2$ in mammals, and $\operatorname{clcn} 2 c$ is more abundant in tissues where ionic exchange with the external medium occurs, like gills and kidney.

Whole embryo in situ hybridization analysis

We also addressed the expression pattern of the three clcn 2 genes during embryonic development. We cloned 1-kb fragments including $3^{\prime}$ UTR from every gene to use as in situ hybridization probes. In the case of $\operatorname{clcn} 2 a$, we could not observe a discrete signal in any stage analyzed $(1,2,3$, and 5 days post-fertilization, dpf), even when we used together two non-overlapping probes. Only a faint and diffuse staining throughout the whole embryo could be seen (data not shown). For $c l c n 2 b$, we could observe at 26-h postfertilization (hpf) staining in the pronephros of the embryo (Fig. $4 a-c$ ), in a region corresponding to the proximal convoluted tubule [37]. We performed a double staining with clcnk, expressed in the distal tubule [55], confirming the identity of the pronephric segment where $c l c n 2 b$ is expressed.

Staining for $c l c n 2 c$ was observed starting at $2 \mathrm{dpf}$ as isolated cells on the surface of the embryo posterior to the head and over the yolk (Fig. 4d). The stained cells increased in number and extension covered during the third and posterior days of development, spreading over the yolk and reaching the tip of the yolk extension (Fig. 4e). At $5 \mathrm{dpf}$, clcn 2 cpositive cells were seen as well in the inferior part of the head, on the branchial arch region (Fig. 4f). Gills will later form in this region, consistent with the high expression levels of $c l c n 2 c$ in adult gills. Sectioning allowed visualizing that the cells were indeed restricted to the skin of the embryo (Fig. 4g). This expression pattern is consistent with these cells being ionocytes, skin cells responsible for ionic homeostasis in teleosts [33].

Human GLIALCAM changes cell localization of zebrafish clc-2 channels

We have previously shown that the mammalian ClC-2 channel interacts with the cell adhesion molecule GlialCAM that functions as an auxiliary subunit [24]. This interaction increases the plasma membrane localization of the channel,
Fig. 3 Zebrafish clcn 2 genes expression in adult tissues using real-time PCR. a clcn $2 a$ relative expression, referred to the value in kidney. $\mathbf{b}$ clcn $2 b$ relative expression, referred to the value in heart. c clcn 2 c relative expression, referred to the value in the heart. $\mathbf{d}$ Relative expression of the three genes in every tissue. Mean values \pm standard error
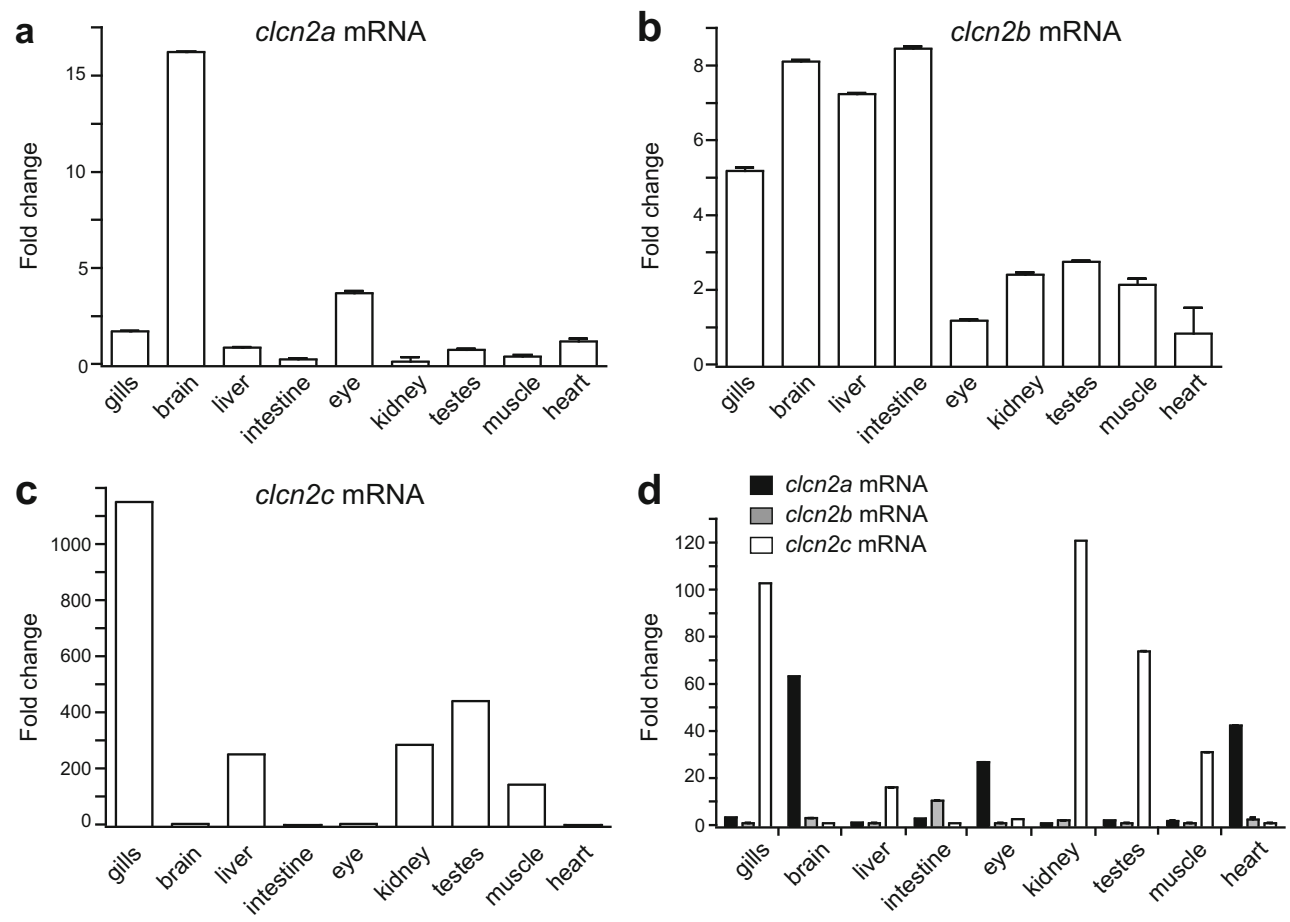

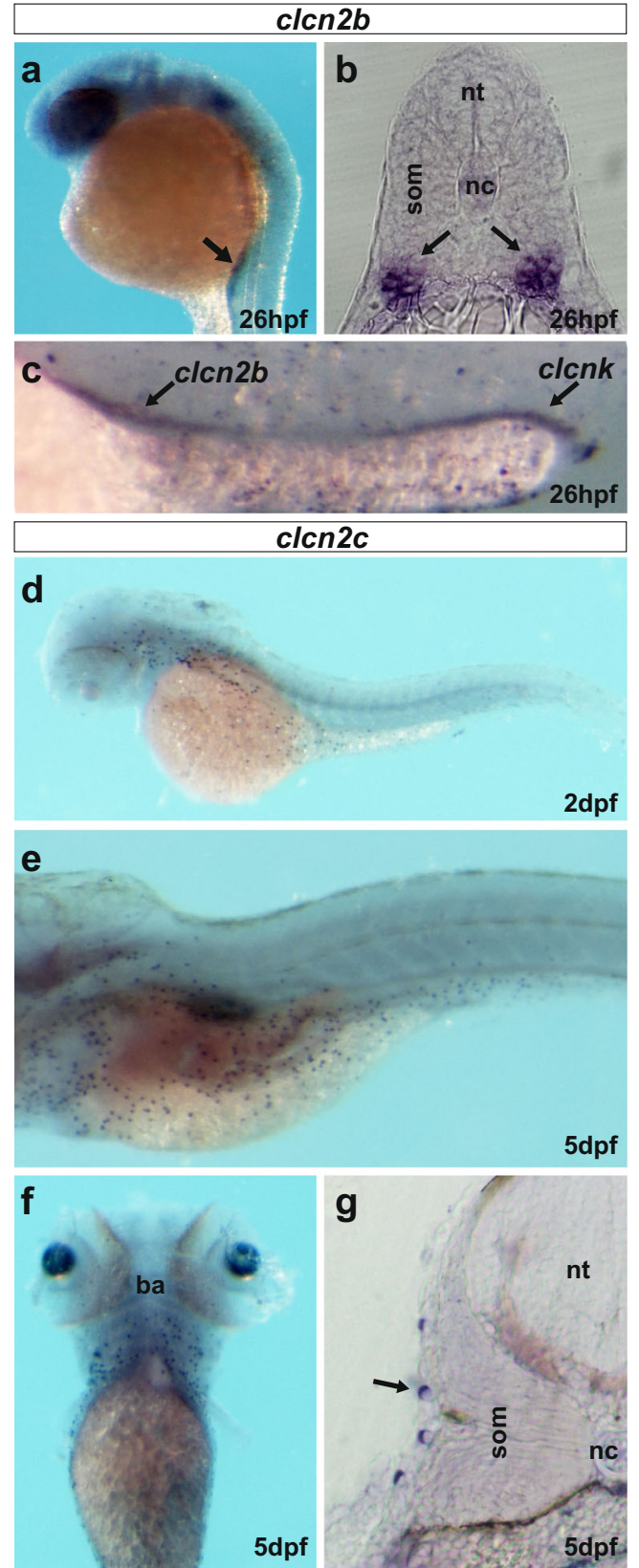

Fig. 4 Zebrafish embryo in situ hybridization. a Lateral view of $c l c n 2 b$ expression in the pronephric tubules (arrow) at $26 \mathrm{hpf}$. b Transverse section at the level of the pronephric tubules, showing bilateral expression of clcn $2 b$. som somite, $n c$ notochord, $n t$ neural tube. c Lateral view of double in situ hybridization with $c l c n 2 b$ and clcnk probes, showing the expression in the proximal convoluted tubule and the distal tubule, respectively. d Lateral view of $\operatorname{clcn} 2 c$ expression at $2 \mathrm{dpf}$, showing expression in isolated cells over the yolk. e Same at $5 \mathrm{dpf}, \mathrm{clcn} 2 \mathrm{c}$ stained cells cover the whole yolk. f Ventral view of $c l c n 2 c$ expression at $5 \mathrm{dpf}$ in the branchial arches (ba). $g$ Transverse section of a 5 dpf embryo at the trunk level showing expression of $c l c n 2 c$ in isolated cells in the skin (arrow)

and specially targets the channel to cell junctions, in both cell lines and primary astrocytes. We wanted to check if this interaction is conserved in the zebrafish clc- 2 channels.
As human ClC-2 (Fig. 5a), the three zebrafish clc-2 channels are mainly localized intracellularly when transfected alone in HeLa cells (Fig. 5d, g, j). When transfected together with human GLIALCAM, zebrafish clc-2a and $\mathrm{b}$ showed a similar behavior as described for human $\mathrm{ClC}-2$ : they were targeted to cell junctions (Fig. 5b, e, h white arrows). clc-2c was also localized in cell junctions when co-expressed with GlialCAM (Fig. 5k), although with lower efficiency, probably due to its reduced expression levels (Fig. S3).

\section{Electrophysiological properties of clc-2 channels}

We expressed in Xenopus oocytes every zebrafish clc-2 paralog and performed two-electrode voltage clamp measurements (Fig. 6a), comparing the activity of uninjected oocytes (Fig. 6b) with that of oocytes expressing human ClC-2 (Fig. 6c). Inwardly rectifying currents were observed for oocytes expressing clc-2a (Fig. 6d) and clc-2b (Fig. 6e). Interestingly, the activation kinetics of currents at negative voltages were faster in clc-2a than in human ClC-2 or clc-2b (Fig. 6c-e). Furthermore, rapidly inactivated instantaneous currents at positive voltages were observed for clc-2a (Fig. 6d). No currents were seen with clc-2c injected oocytes (Fig. 6f).

We then compared the effect of human GlialCAM on clc$2 \mathrm{a}$ and $\mathrm{b}$ with the effects on human ClC-2 (Fig. 7). As already described for rat ClC-2 [24], co-expression of ClC-2 with human GlialCAM (Fig. 7a, b) increased ClC-2-mediated currents, abolished its rectification at positive voltages (Fig. 7c), and they were instantaneously activated (Fig. 7b). Currents mediated by clc- $2 \mathrm{a}$ and $\mathrm{b}$ were also slightly increased by GlialCAM (Fig. 7d-i; Table 1). However, whereas GlialCAM changed the rectification of the clc-2a channel (Fig. 7f), it remained unaltered in the clc-2b channel (Fig. 7i). GlialCAM altered the current characteristics of clc-2a but not from clc$2 \mathrm{~b}$, as assayed by the ratio of resting state currents $\left(\mathrm{I}_{\min }\right)$ and $\mathrm{I}_{\max }$ at $+40 \mathrm{mV}$ (see "Methods" section) (Fig. 7j).

We co-expressed clc-2c with human GlialCAM or with the zebrafish GlialCAM paralogs [47] but no currents could be detected (data not shown). Co-expression of clc-2c with human Barttin [10] also did not result in functional currents (data not shown).

\section{Effects of zebrafish GlialCAM orthologs on clc-2 channels}

As we have previously described [47], there are two GlialCAM paralogs (glialcama and glialcamb) in zebrafish. Similarly to GlialCAM, glialcama could be predominantly detected in cell junctions, while glialcamb was not, and is probably being retained intracellularly. Glialcama was able to modify the current of rat ClC-2, but not glialcamb [47]. Then, we co-expressed glialcama and glialcamb with clc-2a (Fig. 8a, b) or clc-2b (Fig. 8c, d), and compared their current modification with human GlialCAM. 
Fig. 5 Zebrafish clc-2 proteins localization in transfected HeLa cells, alone or together with human GLIALCAM. a-c Human ClC-2 (red) targets to cell

junctions (arrow) in the presence of human GLIALCAM (green). Similar behavior is observed for zebrafish clc-2a (d-f), clc-2b (gi), and clc-2c ( $\mathbf{j}-\mathbf{I})$, although for the latter one with lower

efficiency. Scale bar $1 \mu \mathrm{m}$

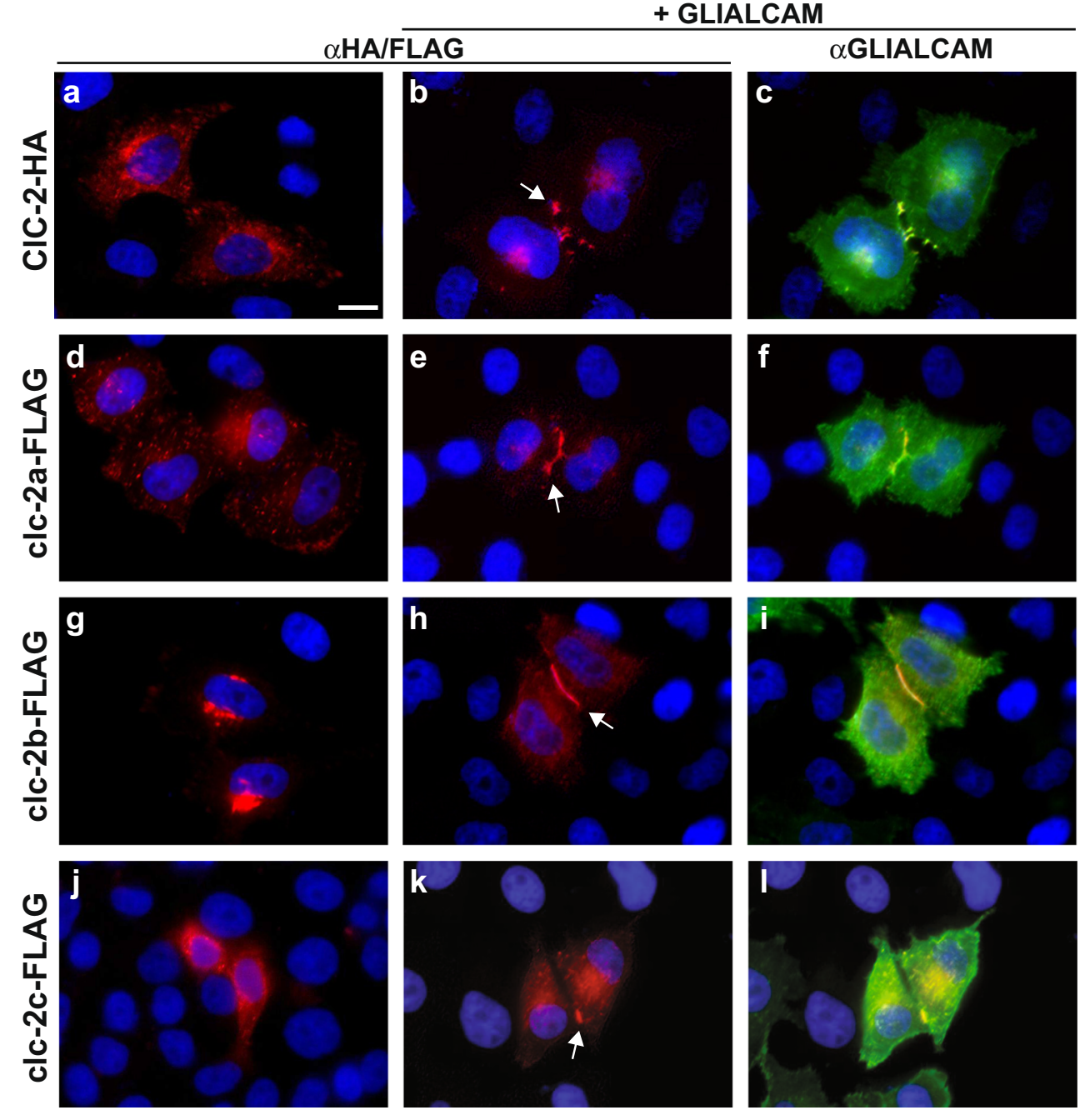

b

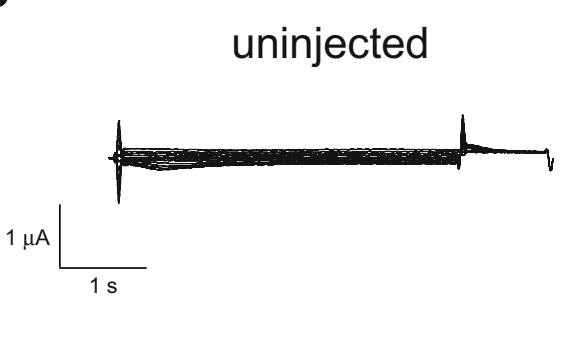

e

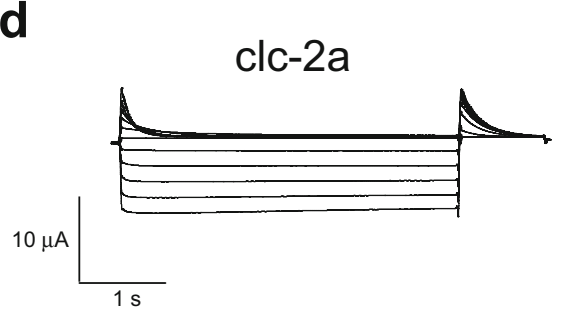

e
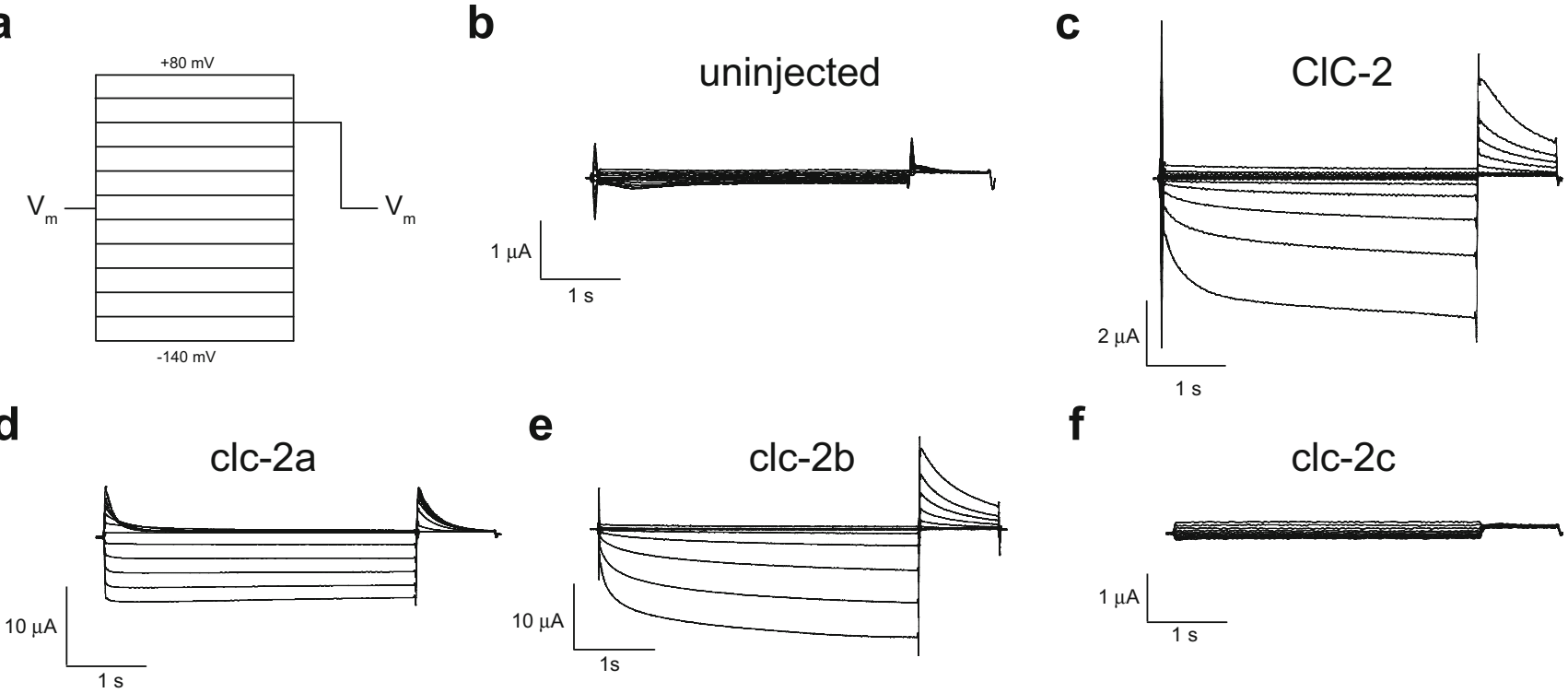

f

clc-2c

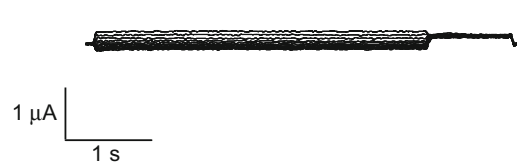

Fig. 6 Zebrafish clc-2-mediated currents in Xenopus oocytes. a Voltage clamp protocol. b Representative current traces obtained in uninjected oocytes (negative control). Currents mediated by human ClC-2 channel (c), clc-2a (d), clc-2b (e), and clc-2c (f) 
a

CIC-2

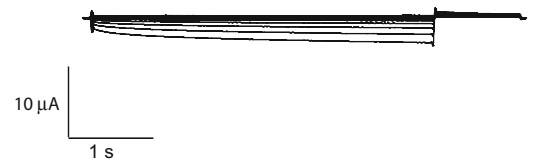

$20 \mu \mathrm{A}$

b $\quad \mathrm{CIC}-2+$ GLIALCAM

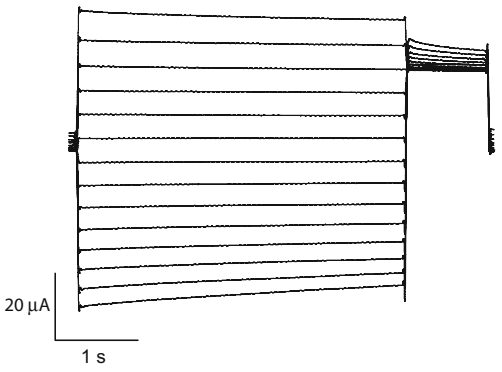

d

clc-2a

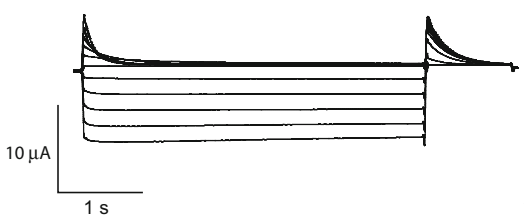

$10 \mu$

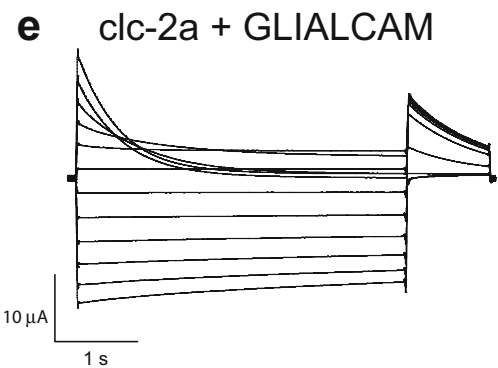

g

clc-2b

h clc-2b + GLIALCAM

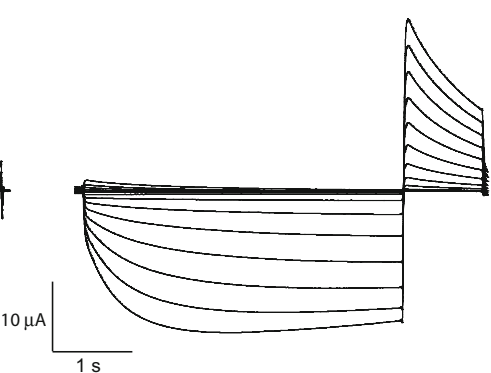

C

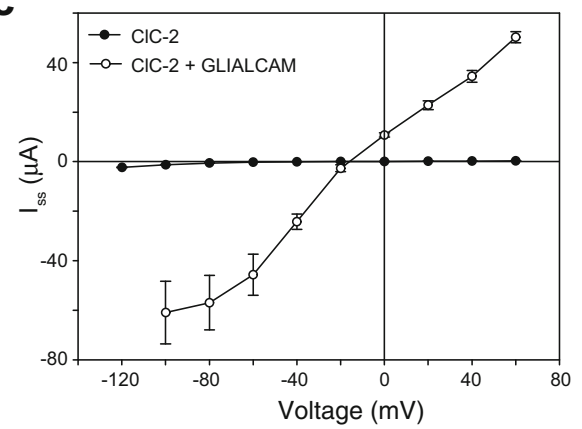

f

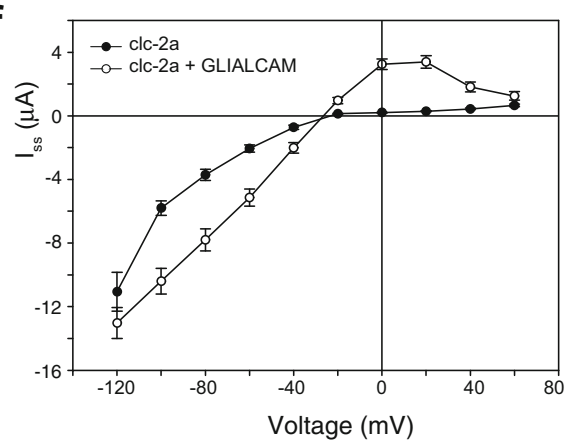

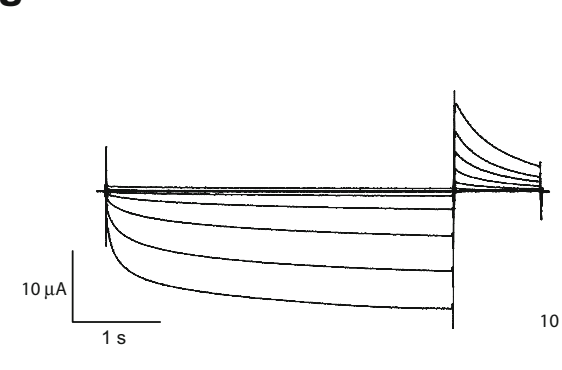

j

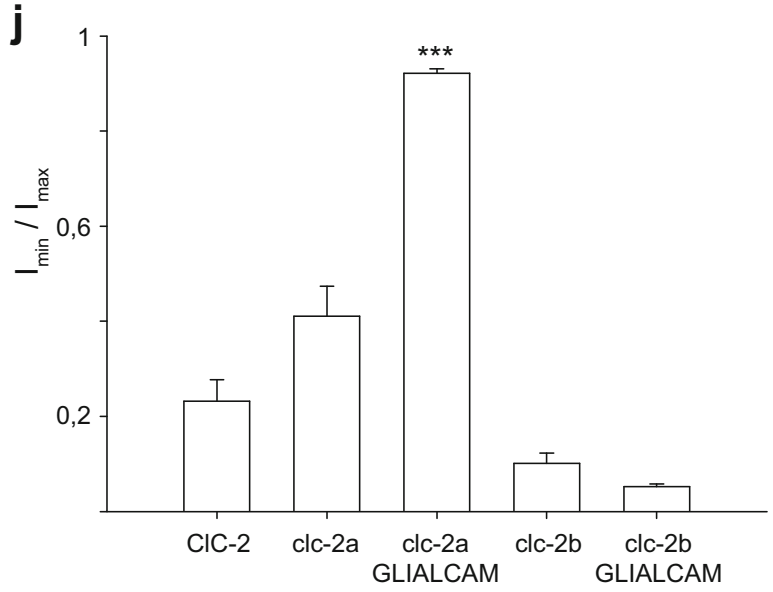

Fig. 7 Human GlialCAM effects on the zebrafish clc-2a and b currents in Xenopus oocytes. a Currents mediated by human $\mathrm{ClC}-2$. b Currents mediated by human ClC-2 after coexpression with human GLIALCAM. c Representative steady-state current-voltage relationship of human $\mathrm{ClC}$ 2 (black, $n=3$ ) and ClC-2 coexpressed with human GLIALCAM (white, $n=3)$. $\mathbf{d}-\mathbf{f}$ Same for zebrafish clc-2a ( $n=16$ for each clc-2a alone and clc2a plus human GLIALCAM). $\mathbf{g}-\mathbf{i}$ Same for zebrafish clc- $2 \mathrm{~b}(n=5$ for each clc- $2 b$ alone and clc- $2 b$ plus human GLIALCAM). Note that the apparent inactivation observed at negative voltages is an artifact caused by anion depletion, as previously described [24]. j GlialCAM alters clc-2a current characteristics as assayed by the ratio of resting state currents $\left(\mathrm{I}_{\min }\right)$ and $\mathrm{I}_{\max }$ at $40 \mathrm{mV}(* * * p<0.001)$, but not those of clc- $2 \mathrm{~b}$. Note that clc-2a has a higher ratio than $\mathrm{ClC}-2$ alone, suggesting that clc-2a has a higher preference for the open state than $\mathrm{ClC}-2$ 
Table 1 Increase of instantaneous slope conductances $(\mu S)$ by GlialCAM

\begin{tabular}{lllll}
\hline & & Increase $_{\text {max }}$ & $p$ value & $n$ \\
\hline$-80 \mathrm{mV}$ & clc-2a & 1 & & 16 \\
& clc-2a+hGC & $1.66 \pm 0.26$ & $* *$ & 16 \\
& clc-2a+gca & $1.19 \pm 0.24$ & NS & 20 \\
& clc-2a+gcb & $0.5 \pm 0.09$ & $* *$ & 15 \\
& clc-2b & 1 & & 5 \\
& clc-2b+hGC & $1.34 \pm 0.28$ & NS & 5 \\
& clc-2b+gca & $1.77 \pm 0.44$ & NS & 5 \\
& clc-2b+gcb & $0.55 \pm 0.21$ & NS & 5 \\
& clc-2a & 1 & & 16 \\
& clc-2a+hGC & $7.14 \pm 1.25$ & $* * *$ & 16 \\
& clc-2a+gca & $4,26 \pm 0,85$ & $* * *$ & 20 \\
& clc-2a+gcb & $0,69 \pm 0,1$ & $*$ & 15 \\
\hline
\end{tabular}

$h G C$ human GLIALCAM, gca zebrafish glialcama, gcb zebrafish glialcamb. Values \pm standard error. NS nonsignificant

${ }^{*} p<0.05 ; * *<<0.01 ; * * * p<0.001$

Glialcama changed the rectification and the amplitude of clc-2a-mediated currents, in a minor degree compared with human GlialCAM (Fig. 8a; Table 1). Similarly, changes in kinetics of activation and inactivation, at negative and positive voltages, respectively, were also observed for glialcama (Fig. 8). Interestingly, co-expression with glialcamb reduced the currents of clc-2a without changing its functional properties (Fig. 8b; Table 1).

In the case of clc-2b, glialcama co-expression resulted in the same effects seen with human GlialCAM: an increase in currents (Fig. 8c; Table 1) without changing the rectification of the current-voltage relationship. Co-expression with glialcamb also reduced the clc-2b-mediated currents.

As described with rat $\mathrm{ClC}-2$, human GlialCAM did not change the ionic selectivity of clc-2a and b (Fig. 8e, f), which is a conserved feature of $\mathrm{ClC}$ proteins. Interestingly, human GlialCAM and glialcama change the $\mathrm{pH}$ sensitivity of the clc2a channel, which indicates that GlialCAM activates the slow gate of clc-2a (Fig. 8g). However, no effect on the $\mathrm{pH}$ dependency was seen for clc-2b, suggesting that the clc-2b common gating was not modified by GlialCAM (Fig. 8h) [23]. Definitive proof that the common gating is not modified may need single channel recordings.

\section{Discussion}

Teleost genomes encode three clc-2 channels

In this work, we have described and characterized the full repertoire of clc-2 channels in zebrafish. The first interesting finding was the number of clcn2 genes in teleost genomes. The teleost fish ancestor experienced an additional whole genome duplication with respect to other vertebrates. This phenomenon has resulted in as many as $15 \%$ of all teleost fish genes to retain two paralogs [19]. After gene duplication, one of the mechanisms leading to gene preservation is subfunctionalization, i.e., the partition of the ancestor expression domains between the paralogs [15].

This seems to be the case for zebrafish clcn $2 a$ and $c l c n 2 b$ genes. These two genes are the most similar in protein sequence to mammalian $\mathrm{ClC}-2$, and the likely result of the whole genome duplication. $\mathrm{ClC}-2$ shows a broad expression pattern, but $c l c n 2 a$ is mostly expressed in adult brain, eye, and heart, while $c l c n 2 b$ presents a more even expression level in most tissues analyzed. This suggests that clcn $2 a$ would be more abundant in excitable tissues, where ClC-2-mediated chloride currents could have a role in regulating neuronal excitability [14, 44, 45] or the cardiac pacemaker activity [20]. On the other hand, clcn $2 b$ would be responsible for the basal chloride currents needed for basic cell functions, still not well understood. During embryonic development, $c l c n 2 b$ is expressed in the proximal convoluted tubule of the pronephros, differently from clcnk, expressed in the distal tubule. This is analogous to the situation in the mammalian kidney, where $\mathrm{ClC}-2$ is expressed in the proximal tubule [41], and $\mathrm{ClC}-\mathrm{Ka}$ and $\mathrm{ClC}-\mathrm{Kb}$ in Henle's loop, convoluted tubule, and collecting duct [27, 28].

The third zebrafish $c l c n 2$ gene $(c l c n 2 c)$ arose from a singlegene duplication event, as indicated by its genomic localization in tandem with $c l c n 2 b$. This is not rare, as it can also be seen in the case of aquaporin aqp 8 , present in the zebrafish genome as aqp8aa and aqp8ab in tandem in chromosome 12 and $a q p 8 b$ in chromosome 3 [52]. clcn2c expression is restricted during embryonic development to a teleost-specific cell type, the ionocytes, and in the adult animal is mostly expressed in the gills. This cell type is responsible for ionic homeostasis in both freshwater and saltwater fish [9]. Several types of ionocytes exist, distinguished by the set of ionic channels and transporters they express. One of them is the so-called NCC cell, involved in $\mathrm{Na}^{+} / \mathrm{Cl}^{-}$uptake, and characterized by the expression of the $\mathrm{Na}^{+}-\mathrm{Cl}^{-}$cotransporter $\mathrm{NCC}$ like 2 (slc12a10.2). It has been long hypothesized that these cells must express a basolateral chloride channel. Although the intracellular $\mathrm{ClC}-3 \mathrm{Cl}^{-} / \mathrm{H}^{+}$exchanger has been involved in osmoregulation in other fish [3], clcn 2 c expression pattern fits with the NCC ionocyte distribution [53]. Therefore, clc-2c could be the chloride channel responsible for chloride uptake in teleosts.

Zebrafish clc-2c is the most divergent regarding protein sequence similarity, while keeping the characteristic features of a ClC-2 member, and it was co-opted into a teleost-specific function. The length of the branches in the phylogenetic tree where the three teleost clc-2c channels are located suggests 
Fig. 8 Electrophysiological characterization of the zebrafish clc-2a and b. a, b Currents mediated by clc- $2 \mathrm{a}$ after coexpression with zebrafish glialcama and glialcamb, respectively. $\mathbf{c}, \mathbf{d}$ Currents mediated by clc- $2 \mathrm{~b}$ after coexpression with glialcama and glialcamb, respectively. e, $\mathbf{f}$ Permeability ratios of clc- $2 \mathrm{a}$ coexpressed with glialcama $(n=5$ \pm SEM), and clc- $2 \mathrm{~b}$ coexpressed with glialcama ( $n=5 \pm \mathrm{SEM}$ ). $\mathbf{k}$, i $\mathrm{pH}$ dependence of clc-2a and clc-2b, each alone or with the different GlialCAM proteins. Currents were normalized to the value at $\mathrm{pH} 6.4$

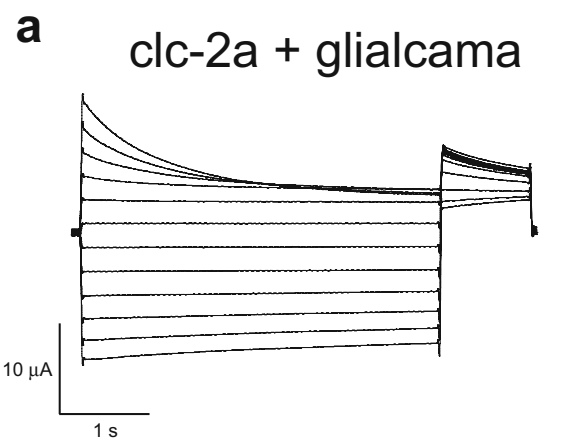

b clc- $2 a+$ glialcamb
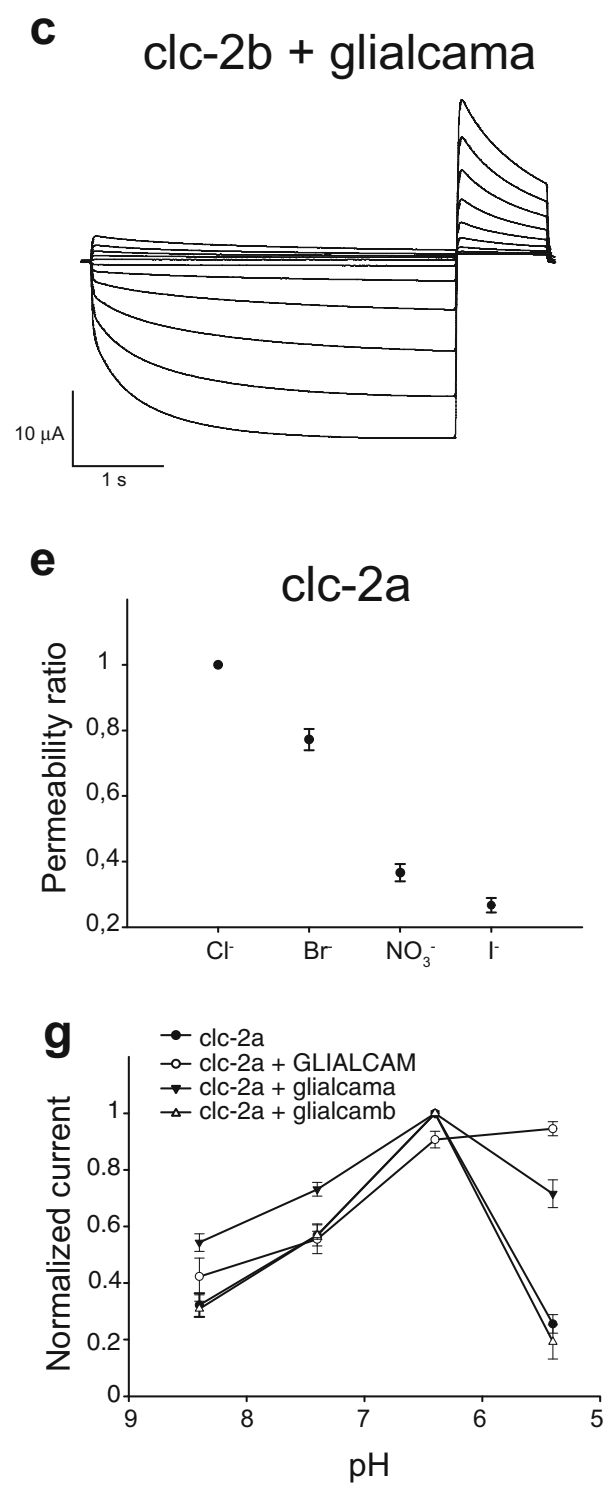

\section{d clc- $2 b+$ glialcamb}
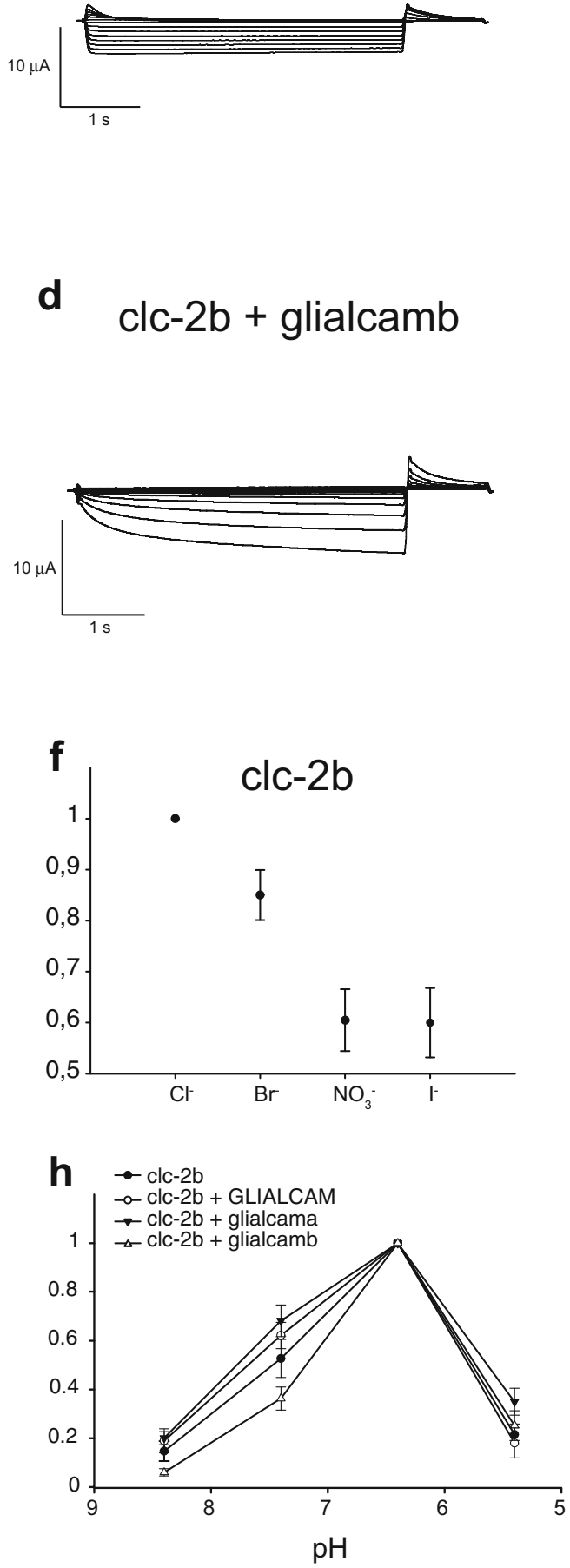

that, after its duplication, it followed a rapid and independent evolutionary pathway in the three teleost lineages analyzed: Characiformes (Mexican tetra), Perciformes (Nile tilapia), and Cypriniformes (zebrafish), all of them native to freshwater habitats. It has been described that there are differences in the genes involved in freshwater adaptation even among different populations of the same species [5], which may explain the sequence differences among them. 
Interaction of zebrafish clc-2 channels with GlialCAM

GlialCAM was identified as a ClC-2 and MLC1 subunit in glial cells [24, 34]. In vivo demonstration of its role was clearly defined by the analysis of GlialCAM ${ }^{\prime-}$ mice, in which ClC-2 was mislocalized in the Bergmann glia [18]. However, GlialCAM is able to interact in vitro with all CLC channels tested (ClC-0, ClC-1, and ClC-K/Barttin) [23], including ClC2 from Drosophila, whose genome does not have a GlialCAM ortholog. In this work, we have identified that GlialCAM targets all clc-2 zebrafish paralogs to cell junctions in cultured cells. GlialCAM not only targets $\mathrm{ClC}-2$ to cell junctions, but also modifies $\mathrm{ClC}-2$ currents. However, putative modification of the common gating was only observed for the clc-2a channel, although clc-2b currents were slightly increased and no clc-2c-mediated currents could be detected. Further work is needed using zebrafish glialcama ${ }^{-/-}$animals to address which clc- 2 channels are regulated by glialcama in vivo.

In zebrafish, there are two GlialCAM paralogs. However, only glialcama is able to target MLC1 and $\mathrm{ClC}-2$ to cell junctions [47]. Although glialcamb is mostly located intracellularly in transfected cells, here we show that it is able to interact with $\mathrm{ClC}-2$, as shown by the current reduction when co-expressing with glialcamb. This reduction maybe due to a reduced plasma membrane expression of the channel, but further work is needed to prove it. Chimeric analyses between glialcama and glialcamb could be useful to understand the domains of GlialCAM involved in the interaction with $\mathrm{ClC}-2$.

\section{Zebrafish clc-2 channels show distinct electrophysiological features}

In this work, we have identified a zebrafish ClC-2 homolog (clc-2a) which shows some functional properties that have not been identified in other $\mathrm{ClC}$ channels, as the extremely fast inactivation at positive voltages and the fast activation at negative voltages. Comparative structure-function studies with this channel could be useful to understand the functional properties of the common gating, which is still poorly understood.

Interestingly, we identified for the first time a $\mathrm{ClC}$ channel (clc-2b) whose rectification of the current-voltage relationship is not modified by GlialCAM. We believe that structurefunction studies with this channel may reveal the ClC-2 protein residues GlialCAM is interacting with.

Finally, we identified a ClC-2 channel (clc-2c) that could not be expressed functionally. One reason for this may be the reduced expression levels of this protein, as detected in transient transfection experiments in HeLa cells. Co-expression with GlialCAM or Barttin did not increase chloride currents. Given its teleost-specific function, clc-2c may need an unknown stimulus for its activation or, as other $\mathrm{ClC}$ channels, may need the interaction with an unknown regulatory subunit to be active.
Acknowledgments We would like to thank Beatriz Gamarra and Lara Sedó for excellent fish care. This work was supported in part by SAF 2012-31486 (RE), ELA 2012-014C2B (RE), and AFM Telethon 201216305 (RE and ABG). RE was awarded within ERA-NET E-RARE-2 framework by ISCIII through CIBERER and with an Icrea Academia Prize. ABG is a Serra Hunter fellow.

\section{References}

1. Blanz J, Schweizer M, Auberson M et al (2007) Leukoencephalopathy upon disruption of the chloride channel ClC-2. J Neurosci 27:65816589. doi:10.1523/JNEUROSCI.0338-07.2007

2. Bosl MR, Stein V, Hubner C et al (2001) Male germ cells and photoreceptors, both dependent on close cell-cell interactions, degenerate upon ClC-2 Cl(-) channel disruption. EMBO J 20:1289-1299. doi:10.1093/emboj/20.6.1289

3. Bossus M, Charmantier G, Blondeau-Bidet E et al (2013) The ClC-3 chloride channel and osmoregulation in the European sea bass, Dicentrarchus labrax. J Comp Physiol B 183:641-662. doi:10. 1007/s00360-012-0737-9

4. Catalan MA, Flores CA, Gonzalez-Begne M et al (2012) Severe defects in absorptive ion transport in distal colons of mice that lack ClC-2 channels. Gastroenterology 142:346-354. doi:10.1053/j. gastro.2011.10.037

5. DeFaveri J, Shikano T, Shimada Y et al (2011) Global analysis of genes involved in freshwater adaptation in threespine sticklebacks (Gasterosteus aculeatus). Evolution 65:1800-1807. doi:10.1111/j. 1558-5646.2011.01247.x

6. Depienne C, Bugiani M, Dupuits C et al (2013) Brain white matter oedema due to ClC-2 chloride channel deficiency: an observational analytical study. Lancet Neurol 12:659-668. doi:10.1016/S14744422(13)70053-X

7. Duran C, Thompson CH, Xiao Q et al (2010) Chloride channels: often enigmatic, rarely predictable. Annu Rev Physiol 72:95-121. doi:10.1146/annurev-physiol-021909-135811

8. Dutzler R, Campbell EB, Cadene M et al (2002) X-ray structure of a $\mathrm{ClC}$ chloride channel at 3.0 A reveals the molecular basis of anion selectivity. Nature 415:287-294. doi:10.1038/415287a

9. Dymowska AK, Hwang PP, Goss GG (2012) Structure and function of ionocytes in the freshwater fish gill. Respir Physiol Neurobiol 184: 282-292. doi:10.1016/j.resp.2012.08.025

10. Estevez R, Boettger T, Stein V et al (2001) Barttin is a Cl- channel beta-subunit crucial for renal Cl- reabsorption and inner ear $\mathrm{K}+$ secretion. Nature 414:558-561. doi:10.1038/35107099

11. Estevez R, Jentsch TJ (2002) CLC chloride channels: correlating structure with function. Curr Opin Struct Biol 12:531-539. doi:10. 1016/S0959-440X(02)00358-5

12. Estevez R, Schroeder BC, Accardi A et al (2003) Conservation of chloride channel structure revealed by an inhibitor binding site in ClC-1. Neuron 38:47-59. doi:10.1016/S0896-6273(03) 00168-5

13. Fahlke C, Fischer M (2010) Physiology and pathophysiology of ClC-K/ Barttin channels. Front Physiol 1:155. doi:10.3389/fphys.2010.00155

14. Foldy C, Lee SH, Morgan RJ et al (2010) Regulation of fast-spiking basket cell synapses by the chloride channel ClC-2. Nat Neurosci 13: 1047-1049. doi:10.1038/nn.2609

15. Force A, Lynch M, Pickett FB et al (1999) Preservation of duplicate genes by complementary, degenerative mutations. Genetics 151: $1531-1545$

16. Grunder S, Thiemann A, Pusch M et al (1992) Regions involved in the opening of CIC-2 chloride channel by voltage and cell volume. Nature 360:759-762. doi:10.1038/360759a0 
17. Grunwald DJ, Eisen JS (2002) Headwaters of the zebrafish-emergence of a new model vertebrate. Nat Rev Genet 3:717-724. doi:10. $1038 /$ nrg892

18. Hoegg-Beiler MB, Sirisi S, Orozco IJ et al (2014) Disrupting MLC1, GLIALCAM and ClC-2 interactions in leukodystrophy entails $\mathrm{Cl}^{-}$ channel dysfunction. Nat Commun 5:3475. doi:10.1038/ ncomms4475

19. Howe K, Clark MD, Torroja CF et al (2013) The zebrafish reference genome sequence and its relationship to the human genome. Nature 496:498-503. doi:10.1038/nature12111

20. Huang ZM, Prasad C, Britton FC et al (2009) Functional role of CLC-2 chloride inward rectifier channels in cardiac sinoatrial nodal pacemaker cells. J Mol Cell Cardiol 47:121-132. doi:10.1016/j. yjmcc.2009.04.008

21. Hwang PP, Chou MY (2013) Zebrafish as an animal model to study ion homeostasis. Pflugers Arch 465:1233-1247. doi:10.1007/ s00424-013-1269-1

22. Jentsch TJ (2008) CLC chloride channels and transporters: from genes to protein structure, pathology and physiology. Crit Rev Biochem Mol Biol 43:3-36. doi:10.1080/10409230701829110

23. Jeworutzki E, Lagostena L, Elorza-Vidal E et al (2014) GlialCAM, a ClC-2 Cl- channel subunit, activates the slow gate of $\mathrm{ClC}$ chloride channels. Biophys J 107:1105-1106. doi:10.1016/j.bpj.2014.07.040

24. Jeworutzki E, Lopez-Hernandez T, Capdevila-Nortes X et al (2012) GlialCAM, a protein defective in a leukodystrophy, serves as a ClC-2 $\mathrm{Cl}(-)$ channel auxiliary subunit. Neuron 73:951-961. doi:10.1016/j. neuron.2011.12.039

25. Jordt SE, Jentsch TJ (1997) Molecular dissection of gating in the ClC-2 chloride channel. EMBO J 16:1582-1592. doi:10.1093/ emboj/16.7.1582

26. Kieferle S, Fong P, Bens M et al (1994) Two highly homologous members of the $\mathrm{ClC}$ chloride channel family in both rat and human kidney. Proc Natl Acad Sci USA 91:6943-6947

27. Kobayashi K, Uchida S, Mizutani S et al (2001) Developmental expression of CLC-K1 in the postnatal rat kidney. Histochem Cell Biol 116:49-56

28. Kobayashi K, Uchida S, Mizutani S et al (2001) Intrarenal and cellular localization of CLC-K2 protein in the mouse kidney. J Am Soc Nephrol 12:1327-1334

29. Koch MC, Steinmeyer K, Lorenz C et al (1992) The skeletal muscle chloride channel in dominant and recessive human myotonia. Science 257:797-800

30. Lange PF, Wartosch L, Jentsch TJ et al (2006) ClC-7 requires Ostm1 as a beta-subunit to support bone resorption and lysosomal function. Nature 440:220-223. doi:10.1038/nature04535

31. Li WH, Yang J, Gu X (2005) Expression divergence between duplicate genes. Trends Genet 21:602-607. doi:10.1016/j.tig.2005.08.006

32. Lieschke GJ, Currie PD (2007) Animal models of human disease: zebrafish swim into view. Nat Rev Genet 8:353-367. doi:10.1038/nrg2091

33. Lin LY, Horng JL, Kunkel JG et al (2006) Proton pump-rich cell secretes acid in skin of zebrafish larvae. Am J Physiol Cell Physiol 290:C371-C378. doi:10.1152/ajpcell.00281.2005

34. Lopez-Hernandez T, Ridder MC, Montolio M et al (2011) Mutant GlialCAM causes megalencephalic leukoencephalopathy with subcortical cysts, benign familial macrocephaly, and macrocephaly with retardation and autism. Am J Hum Genet 88:422-432. doi:10.1016/j. ajhg.2011.02.009

35. Lorenz C, Pusch M, Jentsch TJ (1996) Heteromultimeric CLC chloride channels with novel properties. Proc Natl Acad Sci USA 93: 13362-13366

36. Ludewig U, Pusch M, Jentsch TJ (1996) Two physically distinct pores in the dimeric ClC-0 chloride channel. Nature 383:340-343. doi:10.1038/383340a0

37. McCampbell KK, Wingert RA (2013) New tides: using zebrafish to study renal regeneration. Transl Res 163:109-122. doi:10.1016/j.trsl. 2013.10.003
38. Middleton RE, Pheasant DJ, Miller C (1996) Homodimeric architecture of a ClC-type chloride ion channel. Nature 383:337-340. doi:10. 1038/383337a0

39. Miller C (1982) Open-state substructure of single chloride channels from Torpedo electroplax. Philos Trans R Soc Lond B Biol Sci 299:401-411

40. Nehrke K, Arreola J, Nguyen HV et al (2002) Loss of hyperpolarization-activated $\mathrm{Cl}(-)$ current in salivary acinar cells from Clcn2 knockout mice. J Biol Chem 277:23604-23611. doi: 10.1074/jbc.M202900200

41. Obermuller N, Gretz N, Kriz W et al (1998) The swelling-activated chloride channel $\mathrm{ClC}-2$, the chloride channel $\mathrm{ClC}-3$, and $\mathrm{ClC}-5$, a chloride channel mutated in kidney stone disease, are expressed in distinct subpopulations of renal epithelial cells. J Clin Invest 101: 635-642. doi:10.1172/JCI1496

42. Pfaffl MW (2001) A new mathematical model for relative quantification in real-time RT-PCR. Nucleic Acids Res 29:e45. doi:10.1093/ nar/29.9.e45

43. Phillips JB, Westerfield M (2014) Zebrafish models in translational research: tipping the scales toward advancements in human health. Dis Model Mech 7:739-743. doi:10.1242/dmm.015545

44. Ratte S, Prescott SA (2011) ClC-2 channels regulate neuronal excitability, not intracellular chloride levels. J Neurosci 31:15838-15843. doi:10.1523/JNEUROSCI.2748-11.2011

45. Rinke I, Artmann J, Stein V (2010) ClC-2 voltage-gated channels constitute part of the background conductance and assist chloride extrusion. J Neurosci 30:4776-4786. doi:10.1523/JNEUROSCI. 6299-09.2010

46. Romanenko VG, Nakamoto T, Catalan MA et al (2008) Clcn2 encodes the hyperpolarization-activated chloride channel in the ducts of mouse salivary glands. Am J Physiol Gastrointest Liver Physiol 295:G1058-G1067. doi:10.1152/ajpgi.90384.2008

47. Sirisi S, Folgueira M, Lopez-Hernandez T et al (2014) Megalencephalic Leukoencephalopathy with subcortical Cysts protein 1 regulates glial surface localization of GLIALCAM from fish to humans. Hum Mol Genet. doi:10.1093/hmg/ddu231

48. Steinmeyer K, Klocke R, Ortland C et al (1991) Inactivation of muscle chloride channel by transposon insertion in myotonic mice. Nature 354:304-308. doi:10.1038/354304a0

49. Steinmeyer K, Ortland C, Jentsch TJ (1991) Primary structure and functional expression of a developmentally regulated skeletal muscle chloride channel. Nature 354:301-304. doi:10.1038/354301a0

50. Stolting G, Fischer M, Fahlke C (2014) ClC-1 and ClC-2 form hetero-dimeric channels with novel protopore functions. Pflugers Arch. doi:10.1007/s00424-014-1490-6

51. Thiemann A, Grunder S, Pusch M et al (1992) A chloride channel widely expressed in epithelial and non-epithelial cells. Nature 356: 57-60. doi:10.1038/356057a0

52. Tingaud-Sequeira A, Calusinska M, Finn RN et al (2010) The zebrafish genome encodes the largest vertebrate repertoire of functional aquaporins with dual paralogy and substrate specificities similar to mammals. BMC Evol Biol 10:38. doi:10.1186/1471-2148-10-38

53. Wang YF, Tseng YC, Yan JJ et al (2009) Role of SLC12A10.2, a Na$\mathrm{Cl}$ cotransporter-like protein, in a $\mathrm{Cl}$ uptake mechanism in zebrafish (Danio rerio). Am J Physiol Regul Integr Comp Physiol 296:R1650 R1660. doi:10.1152/ajpregu.00119.2009

54. Weinreich F, Jentsch TJ (2001) Pores formed by single subunits in mixed dimers of different CLC chloride channels. J Biol Chem 276: 2347-2353. doi:10.1074/jbc.M005733200

55. Wingert RA, Selleck R, Yu J et al (2007) The cdx genes and retinoic acid control the positioning and segmentation of the zebrafish pronephros. PLoS Genet 3:1922-1938. doi:10.1371/journal.pgen.0030189

56. Zdebik AA, Cuffe JE, Bertog M et al (2004) Additional disruption of the $\mathrm{ClC}-2 \mathrm{Cl}(-)$ channel does not exacerbate the cystic fibrosis phenotype of cystic fibrosis transmembrane conductance regulator mouse models. J Biol Chem 279:22276-22283. doi:10.1074/jbc. M309899200 